\title{
Development and Validation of Stability Indicating RP HPLC method for the estimation of armodafinil and Characterization of its base Degradation Product by LC-MS/MS
}

\author{
Krishna veni Nagappan*, Neha Sungroya, Dakshyani D S Devi, Sonam Patel, Karthik Y, \\ Gowramma B, Dhanabal S P \\ JSS College of Pharmacy, \\ [A Constituent College of Jagadguru Shree Shivarathreeshwara University, Mysuru] \\ Rocklands, Udhagamandalam, \\ The Nilgiris, Tamilnadu, India
}

\begin{abstract}
The present work focuses on the development and validation of a rapid, selective and reliable stability indicating reverse phase High Performance Liquid Chromatographic method for the quantitative analysis of Armodafinil (ARM). Armodafinil is a eugeroics drug used for treatment of narcolepsy and shift work sleep disorder and also as an adjunctive treatment for obstructive sleep apnea. The separation was carried out on a Hibar Purospher $\mathrm{C}_{18}(250 \mathrm{~mm} \times 4.6 \mathrm{~mm} ; 5 \mu)$ column by using $0.01 \mathrm{M}$ ammonium formate ( $\mathrm{pH} 4.5$, Adjusted with acetic acid) and methanol as mobile phase in the ratio of $45: 55 \% \mathrm{v} / \mathrm{v}$. The flow rate was maintained at $1 \mathrm{~mL} / \mathrm{min}$ and the eluents were monitored at $220 \mathrm{~nm}$. Stress studies were carried out with 1 $\mathrm{mg} / \mathrm{mL}$ of the drug solution, starting with mild conditions and followed by intrinsic conditions to achieve sufficient degradation. Armodafinil underwent extensive degradation under basic hydrolysis condition. The unknown degradation product formed (DP I; 6.59 $\pm 0.2 \mathrm{~min}$ ) under the basic degradation condition was separated on a semi preparative HPLC, characterized by UPLCQ-TOF and its fragmentation pathway was proposed. The proposed structure of the degradation product was confirmed by HRMS analysis. The developed stability indicating LC method was validated with respect to accuracy, precision, specificity/selectivity and linearity. The degradation product was characterized and reported.
\end{abstract}

Keywords- Armodafinil; LC-MS/MS; degradation; Validation.

\section{INTRODUCTION}

The stress testing of pharmaceuticals has long been recognized as an important part in the drug development process. They help in demonstrating the specificity of stability indicating methods and to determine the degradation pathways and degradation product of the active ingredients. These methods are also useful in the investigation of the chemical and physical stability of the crystal forms, the stereo chemical stability of the drug substances \& drug product, mass balance issues and for differentiating drug substances related degradation products in the formulations. The focus on these degradation products are basically due to various health and safety considerations. A subset of these impurities may be genotoxic in nature posing additional safety concern leading to carcinogenicity and genetic mutations.

Armodafinil (ARM), 2-[(R)-(diphenyl methyl) sulfinyl] acetamide, falls under the category of eugeroics. It is used for the treatment of narcolepsy and shift work sleep disorder and also as an adjunctive treatment for obstructive sleep apnea. [1].

Few analytical methods are available for the determination of ARM in bulk and pharmaceutical dosage form by UV [2] and HPLC [3]. Two LC-MS/MS methods were reported for the analysis of ARM in human plasma [4, 5]. Jennifer et al have reported the chiral analysis of $\mathrm{d}$ and 1 modafinil in human plasma and their application to pharmacokinetic studies [6]. Enantioselective separation of modafinil was carried out and quantified by capillary electrophoresis [7]. Rao et al reported an RP-HPLC method for the separation and determination of related substances of modafinil [8] and also an enantioselective HPLC method for the resolution of synthetic intermediates of armodafinil and their related substances [9]. Wei Wang et al have reported the enantiomeric separation and determination of the enantiomeric impurity of armodafinil by capillary electrophoresis with sulfobutyl ether $\beta$ cyclodextrin as chiral selector [10]. Mona Darvish et al had reported a study on a possible interaction between quetiapine and armodafinil in patients with schizophrenia: An open label multiple dose study [11]. Deepti Jain and Pawan K Basniwal had reported the intrinsic stability of armodafinil hydrochloride by forced degradation and impurity profiling [12].

However, this article deals with the development and validation of an isocratic RP HPLC method for the quantification of ARM in bulk drug, its validation as per ICH guidelines [13], semi preparative isolation of the base 
degradation product formed and to elucidate the degradation pathway and plausible structure of the degradation product.

\section{EXPERIMENTAL}

\section{A. Instrumentation}

A Waters HPLC system equipped with 1515 solvent delivery system, 2487 dual wavelength absorbance detector and a Rheodyne $7725 \mathrm{i}$ manual injector with $20 \mu 1$ loop volume were used to carry out the stress degradation studies.

For peak purity and LC/MS studies, a Shimadzu HPLC system equipped with LC 20 AD pump, SPD-M20A PDA detector, ESI-quadrapole mass spectrometer equipped with an SIL-20AC auto sampling units were used. The separation was carried out on a Hibar $\mathrm{C}_{18}(250 \times 4.6 \mathrm{~mm}$, id, $5 \mu \mathrm{m})$ column. The data acquisition and processing were performed using Lab Solutions software. LC-MS/MS studies and accurate mass measurements were performed using 1290 infinity UHPLCquadrapole-time of flight (Q-TOF) mass spectrometer (Agilent Technologies, USA) equipped with ESI source with a mass range and resolution from 50-3200 amu and 40000 FWHM respectively. The data acquisition was performed using Analyst ${ }^{\circledR} \mathrm{QS}$ software.

\section{B. Chemicals}

Armodafinil was obtained as gift sample from Wockhardt Pharmaceuticals, Aurangabad, India. HPLC grade methanol (Qualigens Fine Chemicals, India) and HPLC water (Milli-Q water purification system, France) were used for analysis. Analytical reagent grade of ammonium acetate, acetic acid and sodium hydroxide were procured from S. D. Fine chemicals (Mumbai, India).

\section{High Performance Liquid Chromatography Conditions}

The separation of the degradation samples were carried out on a Hibar $\mathrm{C}_{18}$ column $(250 \times 4.6 \mathrm{~mm}$, id, $5 \mu \mathrm{m})$ with a mobile phase consisting of Ammonium acetate (0.01M; pH 4.5) and methanol in an isocratic elution mode $(45: 55 \% \mathrm{~V} / \mathrm{V})$ at room temperature $\left(16-20^{\circ} \mathrm{C}\right)$. The flow rate was maintained at 1.0 $\mathrm{mL} / \mathrm{min}$. The sample injection volume was $20 \mu \mathrm{L}$ and eluents were monitored at $220 \mathrm{~nm}$. Semi-preparative isolation of armodafinil degradation product was carried out with same mobile phase on Zorbax $\mathrm{C}_{18}(250 \times 9.0 \mathrm{~mm}$, id, $5 \mu \mathrm{m})$ with a sample injection volume of $100 \mu \mathrm{L}$ and the flow rate was maintained at $5.0 \mathrm{~mL} / \mathrm{min}$.

\section{Mass spectrometry conditions for MS/MS}

For MS/MS analysis $10 \mu \mathrm{L}$ of all the samples were injected directly into the source by flow injection mode using Ammonium acetate $(0.01 \mathrm{M} ; \mathrm{pH} 4.5)$ and methanol in the ratio of $45: 55 \% \mathrm{v} / \mathrm{v}$ as mobile phase at a flow rate of $0.5 \mathrm{~mL} / \mathrm{min}$. The mass spectrum was recorded in ESI positive mode. Ultrahigh purity nitrogen and helium were used as curtain and collision gas, respectively. The typical ion source conditions were: nebulizer gas, $60 \mathrm{psi}$; dry temperature, $325^{\circ} \mathrm{C}$; dry gas, $5.0 \mathrm{~mL} / \mathrm{min}$; capillary voltage, $5 \mathrm{kV}$; capillary current, 81.787 $\mathrm{nA}$; vaporizer temperature, $400^{\circ} \mathrm{C}$ and dwell time, $200 \mathrm{~ms}$. For the collision induced dissociation (CID) experiments, the precursor ion was selected using quadrapole analyzer and product ions were analyzed by time of flight analyzer. HRMS data acquisition was performed by the following source conditions: capillary voltage, $5 \mathrm{kV}$; declustering potential (DP) and the collision energy (CE) were $-60 \mathrm{~V}$ and $-10 \mathrm{~V}$, respectively; focusing potential, $220 \mathrm{~V}$; resolution 40,000 (FWHM).

\section{E. Forced Degradation Study}

Forced degradation studies of armodafinil was carried out under acid, alkaline, oxidative, thermal and photolytic stress conditions as per ICH guidelines [14]. A stock solution of ARM $(1 \mathrm{mg} / \mathrm{mL})$ was prepared by dissolving the appropriate amount in a suitable diluent. The stress was induced at a concentration of $100 \mu \mathrm{g} / \mathrm{mL}$; aliquots of samples were withdrawn at different time intervals, neutralized to $\mathrm{pH} \mathrm{5-7,}$ suitably diluted to obtain $10 \mu \mathrm{g} / \mathrm{mL}$ and injected in the optimized chromatographic conditions against appropriate blank for control and stress conditions. Prior to analysis the aliquots of the samples were stored in refrigerator at $4^{\circ} \mathrm{C}$. Prior to HPLC and LC-MS/MS analysis, the sample solutions were filtered through $0.45 \mu \mathrm{m}$ membrane filter.

\section{F. Solution Stability}

The primary stock solution of ARM was suitably diluted in the mobile phase and injected periodically into the column against blank to study the stability of the solution.

\section{G. Preparation of Solutions for Stress Studies}

$100 \mathrm{mg}$ of the ARM was weighed accurately and transferred to a $100 \mathrm{~mL}$ volumetric flask, a small quantity of diluent was added to dissolve the drug and the volume was made up with the diluent (Water: Methanol 45:55 \%v/v). Stress degradation solutions were prepared by diluting $2.5 \mathrm{~mL}$ of the above solution to $25 \mathrm{~mL}$ with $\mathrm{HCl}(1 \mathrm{~N}), \mathrm{NaOH}(0.1 \mathrm{~N})$, water, diluent and hydrogen peroxide $(6 \%)$ respectively for hydrolysis and oxidation. Photo degradation of the sample in solid state was performed under hot sunlight.

\section{H. Acid/Base Hydrolysis}

Stress solutions of $100 \mu \mathrm{g} / \mathrm{mL}$ were prepared in $1 \mathrm{~N} \mathrm{HCl}$ and $0.1 \mathrm{~N} \mathrm{NaOH}$ at room temperature and allowed to stand for $24 \mathrm{hrs}$. Further to increase the extent of degradation, the standard solution $(100 \mu \mathrm{g} / \mathrm{mL})$ prepared in $1 \mathrm{~N} \mathrm{HCl}$ and $0.1 \mathrm{~N}$ $\mathrm{NaOH}$ were refluxed at $50^{\circ}$ and $60^{\circ} \mathrm{C}$ for $24 \mathrm{hrs}$. Samples were withdrawn at regular time intervals, neutralized with $10 \%$ $\mathrm{NaOH}$ for acid hydrolysis samples and $10 \% \mathrm{HCl}$ for base hydrolysis samples. They were then diluted ten times with the mobile phase prior to analysis with the optimized chromatographic conditions.

\section{Degradation in presence of water and diluent}

To assess the stability of ARM in the presence of water and the diluent used for the studies, degradation studies were also carried out in the presence of water and the diluent (Water: Methanol 45:55 \%v/v) used. Stress solutions of $100 \mu \mathrm{g} / \mathrm{mL}$ were prepared in water and diluent at room temperature and allowed to stand for $24 \mathrm{hrs}$. Further to increase the extent of 
degradation, the standard solution $(100 \mu \mathrm{g} / \mathrm{mL})$ prepared in water and diluent were refluxed at $50^{\circ}$ and $60^{\circ} \mathrm{C}$ for $24 \mathrm{hrs}$. Samples were withdrawn at regular time intervals, diluted ten times with the mobile phase prior to analysis with the optimized chromatographic conditions.

\section{J. Oxidation}

Stress solutions of $100 \mu \mathrm{g} / \mathrm{mL}$ were prepared in $6 \%$ hydrogen peroxide at room temperature and allowed to stand for $24 \mathrm{hrs}$. Further to increase the extent of degradation, the standard solution $(100 \mu \mathrm{g} / \mathrm{mL})$ prepared in $6 \%$ hydrogen peroxide were refluxed at $50^{\circ}$ and $60^{\circ} \mathrm{C}$ for $24 \mathrm{hrs}$. Samples were withdrawn at regular time intervals, diluted ten times with the mobile phase prior to analysis with the optimized chromatographic conditions.

\section{K. Photo Degradation}

For photo degradation studies, a known quantity of ARM was weighed in a petridish and exposed to hot sunlight for 72 hrs. The samples withdrawn at regular time intervals were diluted ten times with the mobile phase prior to analysis with the optimized chromatographic conditions.

\section{Purification of Alkali Degradation Product (PD-I)}

The target impurity (DP-I) with retention time of $6.59 \pm 0.2$ min was separated by isocratic elution mode using Zorbax RP $\mathrm{C}_{18}(250 \times 9.0 \mathrm{~mm}$, id, $5 \mu \mathrm{m})$ stationary phase and ammonium acetate $(0.01 \mathrm{M} ; \mathrm{pH} 4.5)$ : Methanol $(45: 55 \% \mathrm{v} / \mathrm{v})$ as mobile phase at a flow rate of $5 \mathrm{~mL} / \mathrm{min}$. The eluents were monitored at $220 \mathrm{~nm}$ and the runtime was $25 \mathrm{~min}$. The isolated compound was re-confirmed by chromatographic analysis, the purity of DP-I was found to be $99.8 \%$ and this sample was used for mass analysis (HR - MS/MS).

\section{RESULTS AND DISCUSSION}

\section{A. Optimisation of Chromatographic Conditions}

Initial separation of ARM was carried out on a Purospher $\mathrm{C}_{18}$ column $(150 \times 4.6 \mathrm{~mm} \mathrm{id}, 3 \mu \mathrm{m})$ and methanol/water as mobile phase by varying the organic phase from $80 \%$ to $40 \%$. ARM was well resolved but with tailing. Hence to obtain a symmetric peak the aqueous phase was replaced with buffer. Ammonium acetate buffer $(0.01 \mathrm{M}) / \mathrm{Methanol}$ was used at different ratios such as 30:70, 40:60, 45:55 and 50:50. Based on the retention time, a ratio of $45: 55 \% \mathrm{v} / \mathrm{v}$ was optimized to achieve retention at about $8.42 \pm 0.2 \mathrm{~min}$. In order to obtain better theoretical plates, trials were performed by varying the $\mathrm{pH}$ of the aqueous phase from 2.5 to 4.5 . A pH of 4.5 was optimized for the analysis.

Hence a better resolution between the ARM and degradation products was achieved with Hibar purospher $\mathrm{C}_{18}$ $(250 \times 4.6 \mathrm{~mm}$ id, $5 \mu \mathrm{m})$ column as stationary phase and ammonium acetate $(0.01 \mathrm{M}, \mathrm{pH} 4.5$ adjusted with acetic acid)/methanol $(45: 55 \% \mathrm{v} / \mathrm{v})$ as mobile phase in isocratic elution mode. The flow rate was maintained at $1 \mathrm{~mL} / \mathrm{min}$, the injection volume was $20 \mu \mathrm{L}$ and the eluents were monitored at $220 \mathrm{~nm}$ with $20 \mathrm{~min}$ as runtime for each analysis. The chromatogram of the standard ARM $(10 \mu \mathrm{g} / \mathrm{mL})$ is shown in
Fig: 1. The method showed good separation between the degradation products formed during the degradation studies under various degradation conditions and ARM. The retention time of the major degradation product formed in acid and base degradation study was $6.59 \pm 0.2 \mathrm{~min}$ (DP-I). The resolution among DP-I, DP-II and ARM was significant and was found to be more than 2. The results were tabulated in table-1. For LCMS/MS and HRMS studies, the same method was used as HPLC, without the replacement of buffer.

\section{B. Validation}

The developed method was validated as per ICH (Q2) guidelines with respect to selectivity, specificity, linearity, accuracy, precision, robustness, limit of detection (LOD)/Limit of Quantification (LOQ). [13]

- Specificity: The samples of forced degradation studies were used to demonstrate the specificity and selectivity of the developed stability indicating analytical method. The study employed the samples generated during the degradation of ARM during photo degradation (exposure to sunlight, $72 \mathrm{hrs}$ ), Hydrolysis $(1 \mathrm{M} \mathrm{HCl}$ - at room temperature, Reflux at $50^{\circ}$ and $60^{\circ} \mathrm{C}$ for $24 \mathrm{hrs}$, $0.1 \mathrm{M} \mathrm{NaOH}$ - room temperature, Reflux at $50^{\circ}$ and $60^{\circ} \mathrm{C}$ for $24 \mathrm{hrs}$, Water - at room temperature, Reflux at $50^{\circ}$ and $60^{\circ} \mathrm{C}$ for $24 \mathrm{hrs}$, Diluent - at room temperature, Reflux at $50^{\circ}$ and $60^{\circ} \mathrm{C}$ for $24 \mathrm{hrs}$ ) and oxidation $(6 \%$ Hydrogen peroxide, at room temperature, Reflux at $50^{\circ}$ and $60^{\circ} \mathrm{C}$ for $24 \mathrm{hrs}$ ). The degradants formed were adequately separated and well resolved from ARM, thus demonstrating the specificity and selectivity of the developed stability indicating analytical method. The peak purity was found to be greater than $99 \%$.

- Linearity and Range: The linearity of the developed method for ARM was studied in the range of 0.5-35 $\mu \mathrm{g} / \mathrm{mL}$ at nine different concentrations. Samples were analyzed in triplicate at nine concentrations. The linear regression equation and correlation coefficient were $\mathrm{Y}$ $=64717 \mathrm{x}+901$ and 0.9987 respectively demonstrating the linearity of the method. The results are tabulated in table-2.

- Accuracy: The accuracy of the method was measured in terms of recovery studies using standard addition method at 80,100 and $120 \%$ levels of the sample concentration. The results were carried out in triplicate and the recoveries of the drug was calculated from the difference in peak areas of the fortified and unfortified samples. Excellent recoveries were observed between 98-102\%. (Table-2)

- Precision: The intra and inter day precision was assessed using three quality control samples in the linearity range. Six replicates were analysed to determine the intraday precision. The inter day precision of the method was determined by repeating the procedure six times over three days. The \% RSD values for the intra and inter day precision studies were $<2 \%$, indicating that the developed analytical method is precise. (Table-2) 
- Limit of detection and Limit of Quantification: The sensitivity of the analytical method was expressed in terms of LOD and LOQ which represent the concentration of analyte that would yield a signal to noise ratio of 3 for LOD and 10 for LOQ. The LOD and LOQ were found to be 0.1 and $0.3 \mu \mathrm{g} / \mathrm{mL}$ respectively. This was confirmed by preparing and analyzing these predicted concentrations in triplicate with the optimized chromatographic conditions. (Table-2)

- Robustness \& Ruggedness: The robustness of the method was determined by making small but deliberate changes in the method parameters such as change in flow rate $( \pm 0.2 \mathrm{~mL})$ and $\mathrm{pH}(( \pm 0.1$ units $)$. The resolutions between the closely eluting peaks were greater than 2 demonstrating that the method is robust. The ruggedness of the method was checked by different analyst on different instruments (Shimadzu and Agilent HPLC). The critical parameters were assessed and found to be within the limits indicating the ruggedness of the developed analytical method.

\section{Forced degradation studies}

- Acid induced Degradation: ARM on treatment with $1 \mathrm{~N} \mathrm{HCl}$ at room temperature for $24 \mathrm{hrs}$ showed $6.20 \%$ degradation. To enhance the rate of degradation ARM on treatment with $1 \mathrm{~N} \mathrm{HCl}$ was refluxed for $24 \mathrm{hrs}$ at $50^{\circ}$ and $60^{\circ} \mathrm{C}$, which showed 13.82 and $34.33 \%$ degradation. One degradant (DP I) was observed at the Rt of 6.49 min under all the conditions. The area \% of the degradant was $1.59,1.70$ and 2.63 respectively when exposed to $1 \mathrm{~N} \mathrm{HCl}$ at $\mathrm{RT}$ (room temperature), reflux at $50^{\circ}$ and $60^{\circ} \mathrm{C}$ for $24 \mathrm{hrs}$ respectively. The assay \% of ARM after $24 \mathrm{hrs}$ in $1 \mathrm{~N} \mathrm{HCl}$ at RT, reflux at $50^{\circ}$ and $60^{\circ} \mathrm{C}$ was $98.32 \%, 99.28 \%$ and $75.44 \%$ respectively (Table- 3 ). The chromatogram of acid induced degradation at room temperature is shown in Fig. 2.

- Base induced Degradation: When ARM was subjected to basic degradation with $0.1 \mathrm{~N} \mathrm{NaOH}$ at room temperature showed $99.91 \%$ degradation. Also ARM was subjected to intrinsic degradation by refluxing at $50^{\circ}$ and $60^{\circ} \mathrm{C}$ for $24 \mathrm{hrs}$. One degradant (DP I) eluted at Rt of 6.42 min when the sample was subjected to base hydrolysis at room temperature for $24 \mathrm{hrs}$. Whereas under reflux conditions the drug completely degraded with the formation of two degradation products at the retention times of $6.42 \mathrm{~min}$ and $9.34 \mathrm{~min}$. The area $\%$ of the degradant DP I was $99.89 \%$ and assay \% of ARM was $0.11 \%$ at room temperature. Under intrinsic conditions (reflux at $50^{\circ}$ and $60^{\circ} \mathrm{C}$ for 24 hrs) the area \% of degradants DP I and DP II, were found to be $98.49,0.58 \%$ and $97.66,2.63 \%$ respectively at $50^{\circ}$ and $60^{\circ} \mathrm{C}$. Also the assay $\%$ of ARM was found to be 0.11 and $0.014 \%$ during reflux at $50^{\circ}$ and $60^{\circ} \mathrm{C}$ for $24 \mathrm{hrs}$ (Table-3). The chromatogram of base induced degradation is shown in Fig. 3.

- Degradation in presence of water and diluent: When ARM was treated with water and diluent (Methanol: water, 55:45\%w/w) for $24 \mathrm{hrs}$ at room temperature, no degradation was observed. Further the samples were also studied under intrinsic conditions of refluxing with water and diluent at $50^{\circ}$ and $60^{\circ} \mathrm{C}$ for $24 \mathrm{hrs}$. No degradation products were observed under intrinsic conditions. With water the assay \% of ARM was found to be 99.03, 98.22 and $96.97 \%$ respectively at room temperature, reflux at $50^{\circ}$ and $60^{\circ} \mathrm{C}$ for $24 \mathrm{hrs}$. Whereas with the diluent assay \% of ARM was found to be $99.72,96.88$ and $94.63 \%$ respectively at room temperature, reflux at $50^{\circ}$ and $60^{\circ} \mathrm{C}$ for 24 hrs (Table-3). The chromatograms of the water and solvent induced degradation are shown in Fig. 4,5 .

- Oxidative degradation: When ARM was treated with $6 \% \mathrm{H}_{2} \mathrm{O}_{2}$ for $24 \mathrm{hrs}$ at room temperature, only $5 \%$ of degradation was observed and the assay of ARM was found to be $96.32 \%$. To enhance the rate of degradation $\mathrm{ARM}$ was treated with $6 \% \mathrm{H}_{2} \mathrm{O}_{2}$ and was refluxed at $50^{\circ}$ and $60^{\circ} \mathrm{C}$ for $24 \mathrm{hrs}$. No degradation products were observed and the assay \% of ARM was found to be 94.97 and $94.11 \%$ respectively when refluxed at $50^{\circ}$ and $60^{\circ} \mathrm{C}$ for $24 \mathrm{hrs}$ (Table-3). The chromatograms of the oxidative degradation are shown in Fig. 6.

- Photo degradation: When ARM was exposed to hot sunlight for $72 \mathrm{hrs}$ (hot sunny light equivalent to 18 times of 1.2 million lux hrs) $11.56 \%$ of degradation was observed with the formation of one degradation product at Rt of $6.79 \mathrm{~min}$. The area $\%$ of the degradant (DP I) was $0.07 \%$ and the $\%$ assay of ARM was found to be $99.93 \%$ (Table3 ). The chromatograms of photo degradation are shown in Fig. 7.

\section{Degradation behavior of Armodafinil}

From the degradation studies carried out under acid/base/neutral hydrolysis, oxidation and photolytic conditions, it was observed that the drug undergoes extensive degradation under base hydrolysis. Only one degradation product (DP-I) was formed under acid hydrolysis and photolytic conditions. But under intrinsic conditions of base hydrolysis two degradation products were observed (DP-I, DPII). The retention of DP-I was $6.59 \pm 0.2 \mathrm{~min}$ and DP-II was found to be $9.34 \pm 0.2 \mathrm{~min}$. Since the $\%$ of degradation under base hydrolysis was about $99 \%$, the DP-I was isolated from the base hydrolysis samples by subjecting them to semi preparative HPLC conditions. The chromatographic and system suitability parameters such as Rt, RRT, peak purity, resolution, tailing factor, theoretical plates and asymmetry factor for ARM and DP-II are reported in Table-1. 


\section{E. Characterization studies by LC-MS/MS studies}

The isolated target impurity (DP-I) was subjected to LCMS/MS analysis. (Fig.8)

The hydrolysis of ARM under basic condition yielded two degradation products (DP-I, DP-II) in the presence of $0.1 \mathrm{~N}$ $\mathrm{NaOH}$ at room temperature for $24 \mathrm{hrs}$. Since DP-I was the major degradation product, it was further isolated for chemical characterization. The molecular ion peak of DP-I appeared at an $\mathrm{m} / \mathrm{z}$ of $261(\mathrm{M}+3 \mathrm{H})$. The formation of this ion may be due to the hydrolysis of the amide moiety (release of Ammonia) leading to the formation of aromatic aldehyde. The major $\mathrm{MS}^{\mathrm{n}}$ fragment ions of DP-I were observed at $\mathrm{m} / \mathrm{z} 218$ and 169. The $\mathrm{m} / \mathrm{z}$ at $218[\mathrm{M}+2 \mathrm{H} ; 2-(($ diphenyl methyl) hydroxyl) sulfonium ion] may be formed due to the loss of $-\mathrm{CH}_{2} \mathrm{CHO}$ ion from $\mathrm{m} / \mathrm{z}$ 261. Further elimination of the sulphonyl group may lead to the formation of the base peak at $\mathrm{m} / \mathrm{z} 169[\mathrm{M}+2 \mathrm{H}$; di phenyl methylium ion]. Based on the $\mathrm{MS}^{\mathrm{n}}$ fragmentation studies DP-I and the formation of base peak at $\mathrm{m} / \mathrm{z} 169$, the DP-I was further identified as 2-(benzhydryl sulpinyl) aldehyde which is also supported by the literature [12]. The plausible structure of DP-I, and the fragmentation pathway are shown in Fig. 9.

TABLE I. SYSTEM SUITABILITY PARAMETERS OF ARMODAFINIL AND ITS DEGRADATION PRODUCT DP-I

\begin{tabular}{|l|c|c|c|c|c|c|c|}
\hline \multirow{2}{*}{$\begin{array}{c}\text { comp } \\
\text { ound }\end{array}$} & \multicolumn{7}{|c|}{ System suitability parameters } \\
\cline { 2 - 8 } & $\begin{array}{c}\boldsymbol{R} \boldsymbol{t} \\
\text { min })\end{array}$ & $\boldsymbol{R} \boldsymbol{R T}$ & $\boldsymbol{P P I}$ & $\boldsymbol{R}$ & $\boldsymbol{T f}$ & $\boldsymbol{A s}$ & $\boldsymbol{N}$ \\
\hline $\mathrm{DP}-\mathrm{I}$ & $\begin{array}{c}6.59 \\
\pm 0.2\end{array}$ & 0 & 0.99 & 0 & 0.98 & 1.05 & 13966 \\
\hline $\mathrm{ARM}$ & $\begin{array}{c}8.41 \\
\pm 0.2\end{array}$ & 1.28 & 0.99 & 2.25 & 0.97 & 0.96 & 14238 \\
\hline
\end{tabular}

TABLE II. VALIDATION SUMMARY

\begin{tabular}{|c|c|}
\hline \multicolumn{2}{|c|}{ Validation summary } \\
\hline \multicolumn{2}{|c|}{ Accuracy (\% Mean Recovery \pm SD; $\%$ RSD) } \\
\hline Concentration spiked level $1^{\mathrm{x}}$ & $99.76 \pm 0.45 ; 0.58$ \\
\hline Concentration spiked level $2^{\mathrm{x}}$ & $99.88 \pm 0.75 ; 0.67$ \\
\hline Concentration spiked level $3^{x}$ & $99.02 \pm 0.64 ; 0.54$ \\
\hline \multicolumn{2}{|l|}{ Linearity } \\
\hline Linearity range & $0.5-35 \mu \mathrm{g} / \mathrm{ml}$ \\
\hline Slope & 64717 \\
\hline Intercept & 901 \\
\hline Correlation coefficient & 0.9987 \\
\hline \multicolumn{2}{|l|}{ Precision } \\
\hline \multicolumn{2}{|c|}{ Intraday precision ( $\%$ Mean Recovery \pm SD; \%RSD) } \\
\hline Concentration spiked level $1^{\mathrm{y}}$ & $10.05 \pm 0.03 ; 0.31$ \\
\hline Concentration spiked level $2^{y}$ & $19.93 \pm 0.20 ; 1.02$ \\
\hline Concentration spiked level $3^{y}$ & $29.98 \pm 0.19 ; 0.62$ \\
\hline \multicolumn{2}{|c|}{ Interday precision ( $\%$ Mean Recovery \pm SD; $\%$ RSD) } \\
\hline Concentration spiked level $1^{\mathrm{y}}$ & $10.04 \pm 0.05 ; 0.49$ \\
\hline Concentration spiked level $2^{y}$ & $19.97 \pm 0.36 ; 1.82$ \\
\hline Concentration spiked level $3^{y}$ & $29.96 \pm 0.19 ; 1.37$ \\
\hline \multicolumn{2}{|l|}{ Sensitivity } \\
\hline Limit of Detection & $0.100 \mu \mathrm{g} / \mathrm{ml}$ \\
\hline Limit of Quantification & $0.300 \mu \mathrm{g} / \mathrm{ml}$ \\
\hline
\end{tabular}

concentration -level $1=10 \mu \mathrm{g} / \mathrm{ml}$; concentration -level $2=20 \mu \mathrm{g} / \mathrm{ml}$; concentration -level $3=30$ $\mu \mathrm{g} / \mathrm{ml} ;{ }^{\mathrm{x}}$ Average of three determinations; ${ }^{y}$ Average of six determinations
TABLE III. DEGRADATION DATA OF ARMODAFINIL

\begin{tabular}{|c|c|c|c|c|}
\hline \multirow[b]{2}{*}{$\begin{array}{c}\text { Stress } \\
\text { condition }\end{array}$} & \multicolumn{4}{|c|}{ Degradation data of Armodafinil } \\
\hline & $\begin{array}{c}\text { No of } \\
\text { degradants }\end{array}$ & $\begin{array}{c}\text { Retention } \\
\text { time (min) }\end{array}$ & $\begin{array}{c}\% \\
\text { Degradation } \\
\text { at } t_{R}\end{array}$ & $\begin{array}{c}\% \\
\text { Assay } \\
\text { of } A R M\end{array}$ \\
\hline $\begin{array}{l}1 \mathrm{~N} \mathrm{HCl}(\mathrm{RT}, \\
24 \mathrm{hrs})\end{array}$ & 1 & DP-I: 6.49 & 1.59 & 98.32 \\
\hline $\begin{array}{lr}\mathrm{N} & \mathrm{HCl} \\
\left(50^{\circ} \mathrm{C},\right. & 24 \\
\mathrm{hrs}) & \\
\end{array}$ & 1 & DP-I: 6.49 & 1.70 & 99.28 \\
\hline $\begin{array}{lr}1 \mathrm{~N} & \mathrm{HCl} \\
\left(60^{\circ} \mathrm{C},\right. & 24 \\
\mathrm{hrs}) & \\
\end{array}$ & 1 & DP-I: 6.82 & 2.63 & 75.44 \\
\hline $\begin{array}{l}0.1 \mathrm{~N} \quad \mathrm{NaOH} \\
\text { (RT, } 24 \text { hrs) }\end{array}$ & 1 & DP-I: 6.42 & 88.16 & 9.52 \\
\hline $\begin{array}{lr}0.1 \mathrm{~N} & \mathrm{NaOH} \\
\left(50^{\circ} \mathrm{C},\right. & 24 \\
\mathrm{hrs}) & \\
\end{array}$ & 2 & $\begin{array}{l}\text { DP-I: } 6.42 \\
\text { DP-II: } 9.34\end{array}$ & $\begin{array}{c}98.49 \\
0.58\end{array}$ & 0.11 \\
\hline $\begin{array}{lr}0.1 \mathrm{~N} & \mathrm{NaOH} \\
\left(60^{\circ} \mathrm{C},\right. & 24 \\
\mathrm{hrs}) & \\
\end{array}$ & 2 & $\begin{array}{l}\text { DP-I: } 6.42 \\
\text { DP-II: } 9.33\end{array}$ & $\begin{array}{c}97.66 \\
2.63\end{array}$ & 0.014 \\
\hline $\begin{array}{l}\text { Water (RT, } \\
24 \mathrm{hrs})\end{array}$ & - & - & - & 99.03 \\
\hline $\begin{array}{l}\text { Water }\left(50^{\circ} \mathrm{C},\right. \\
24 \mathrm{hrs})\end{array}$ & - & - & - & 98.22 \\
\hline $\begin{array}{l}\text { Water }\left(60^{\circ} \mathrm{C},\right. \\
24 \mathrm{hrs})\end{array}$ & - & - & - & 96.97 \\
\hline $\begin{array}{l}\text { Diluent (RT, } \\
24 \mathrm{hrs} \text { ) }\end{array}$ & - & - & - & 99.7 \\
\hline $\begin{array}{l}\text { Diluent } \\
\left(50^{\circ} \mathrm{C}, 24\right. \\
\mathrm{hrs})\end{array}$ & - & - & - & 96.88 \\
\hline $\begin{array}{l}\text { Diluent } \\
\left(60^{\circ} \mathrm{C}, 24\right. \\
\text { hrs })\end{array}$ & - & - & - & 94.63 \\
\hline $\begin{array}{ll}6 \% & \mathrm{H}_{2} \mathrm{O}_{2} \\
(\mathrm{RT}, 24 \mathrm{hrs})\end{array}$ & - & - & - & 98.43 \\
\hline $\begin{array}{l}6 \% \quad \mathrm{H}_{2} \mathrm{O}_{2} \\
\left(50^{\circ} \mathrm{C}, 24\right. \\
\mathrm{hrs})\end{array}$ & - & - & - & 94.97 \\
\hline $\begin{array}{l}6 \% \quad \mathrm{H}_{2} \mathrm{O}_{2} \\
\left(60^{\circ} \mathrm{C}, 24\right. \\
\mathrm{hrs})\end{array}$ & - & - & - & 94.11 \\
\hline $\begin{array}{l}\text { Sunlight (72 } \\
\text { hrs) }\end{array}$ & 1 & 6.71 & 0.63 & 97.36 \\
\hline
\end{tabular}

TABLE IV. ELEMENTAL COMPOSITION OF DP-I IN MS/MS SPECTRRA

\begin{tabular}{|c|l|c|c|}
\hline \multirow{3}{*}{ Analyte } & \multicolumn{3}{|c|}{ Elemental composition of DP-I in MS/MS spectra } \\
\cline { 2 - 4 } & $\begin{array}{l}\text { Observed } \\
\text { ion mass }\end{array}$ & $\begin{array}{c}\text { Proposed } \\
\text { formula }\end{array}$ & $\begin{array}{c}\text { Calculated } \\
\text { mass }\end{array}$ \\
\hline \multirow{3}{*}{ DP-I } & 261.1044 & $\mathrm{C}_{15} \mathrm{H}_{14} \mathrm{O}_{2} \mathrm{~S}$ & 261.0949 \\
\cline { 2 - 4 } & 218.1887 & $\mathrm{C}_{13} \mathrm{H}_{12} \mathrm{OS}$ & 218.0765 \\
\cline { 2 - 4 } & 169.9697 & $\mathrm{C}_{13} \mathrm{H}_{12}$ & 170.1096 \\
\hline
\end{tabular}




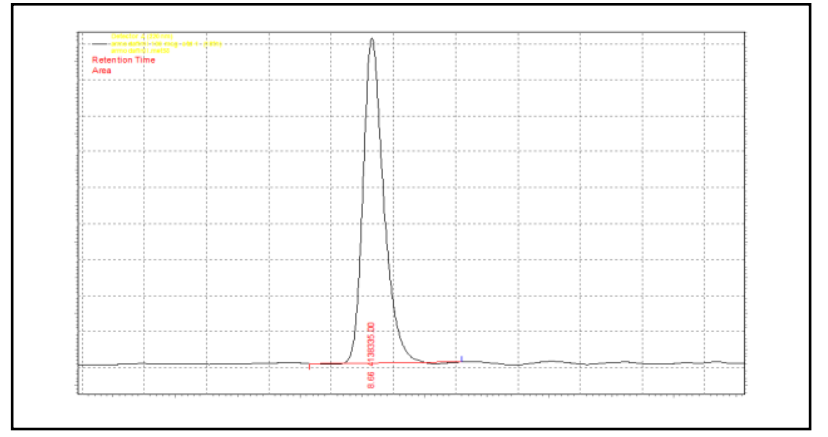

Fig 1: Typical Chromatogram of standard Armodafinil

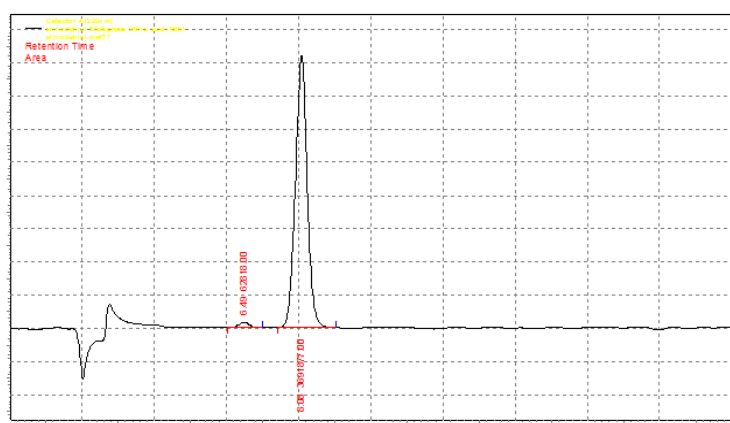

Fig 2: Chromatogram of Acid degradation sample with $1 \mathrm{~N} \mathrm{HCl}$ at room temperature after $24 \mathrm{hrs}$

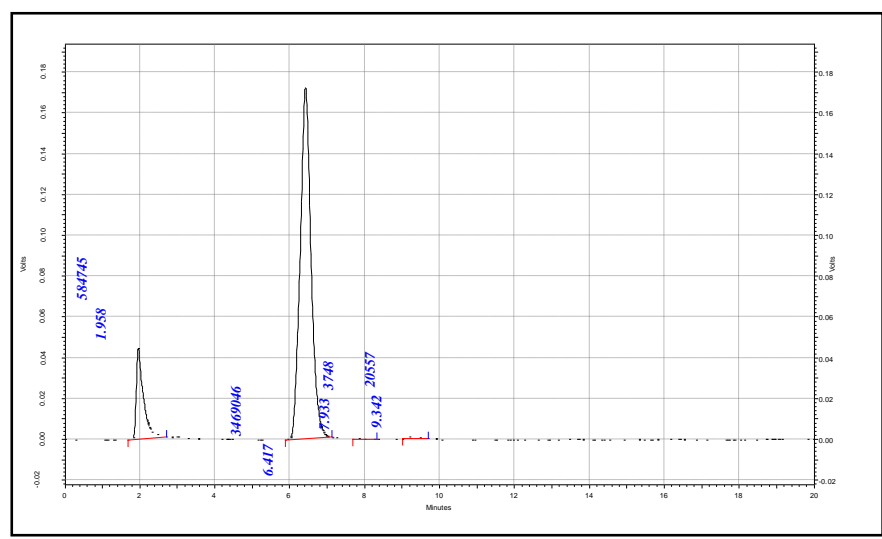

Fig 3: Chromatogram of base degradation sample with $0.1 \mathrm{~N} \mathrm{NaOH}$ at room temperature after $24 \mathrm{hrs}$

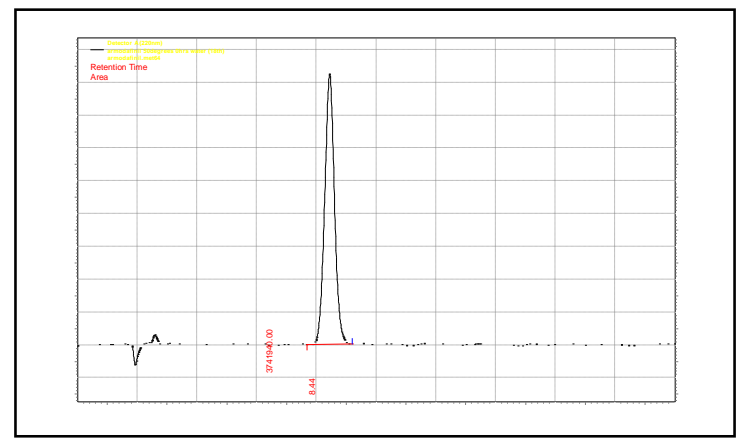

Fig 4: Chromatogram of neutral degradation sample with water at room temperature after $24 \mathrm{hrs}$

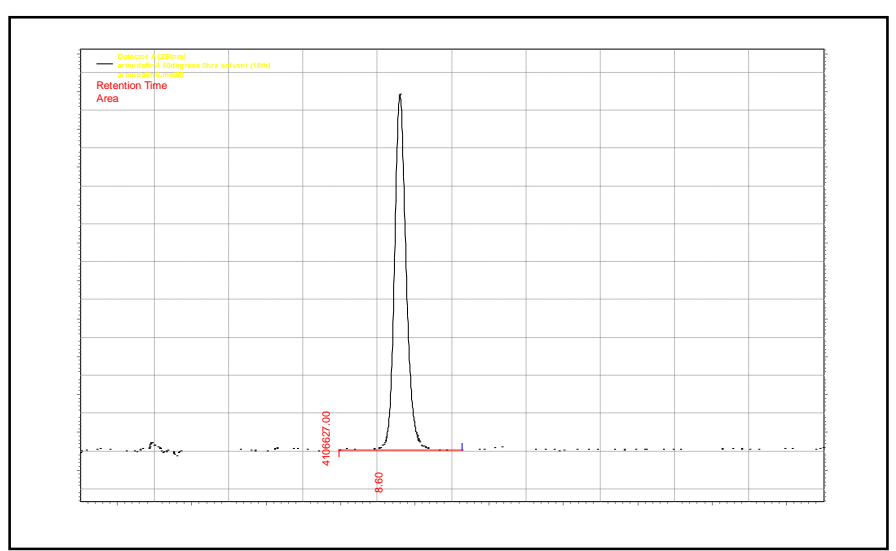

Fig 5: Chromatogram of neutral degradation sample with diluent at room temperature after $24 \mathrm{hrs}$

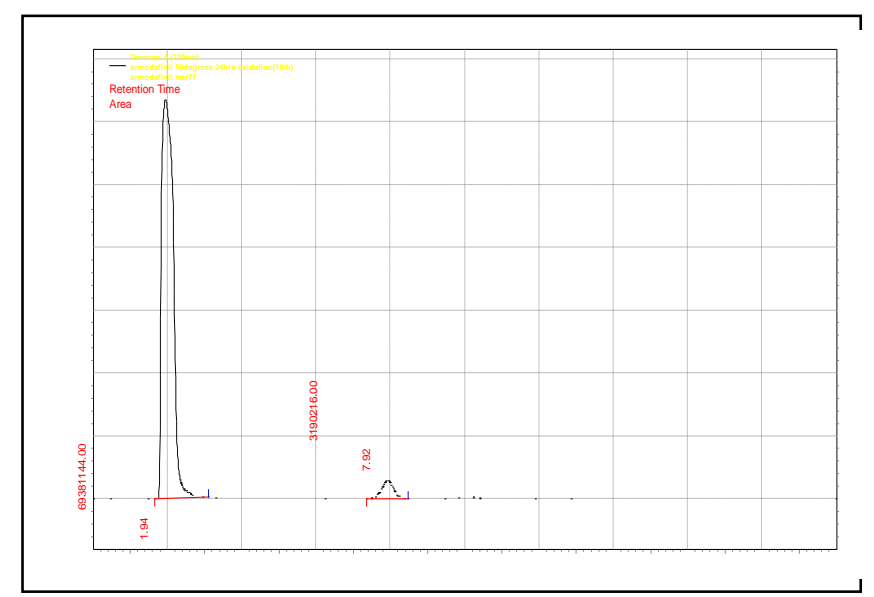

Fig 6: Chromatogram of oxidative degradation sample with $6 \% \mathrm{H}_{2} \mathrm{O}_{2}$ at room temperature after $24 \mathrm{hrs}$ 


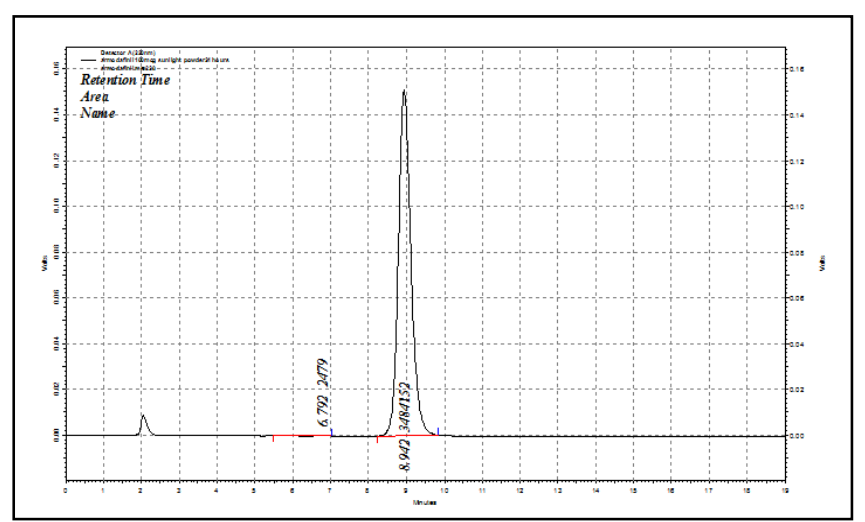

Fig 7: Chromatogram of oxidative degradation sample with $6 \% \mathrm{H}_{2} \mathrm{O}_{2}$ at room temperature after $24 \mathrm{hrs}$
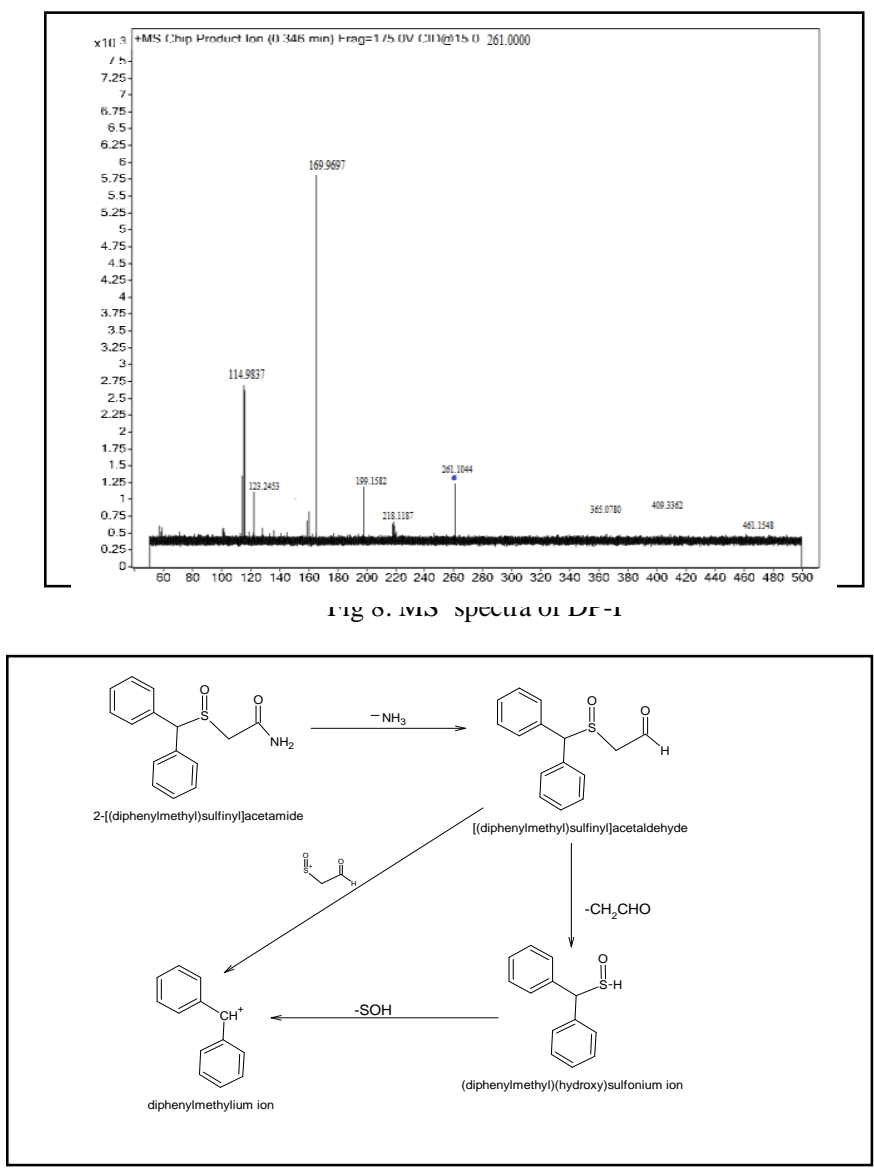

Fig 9: Plausible degradation pathway of base degradation product DP-I

\section{CONCLUSION}

A simple, sensitive and specific stability indicating RP HPLC method was developed for the analysis of ARM in bulk drug and validated as per ICH guidelines. One degradation product was formed during the base degradation studies and it was well resolved from the API by the proposed LC method. The proposed structure of the base degradation product was characterized by $\mathrm{MS}^{\mathrm{n}}$ studies and further confirmed by HR-MS data and accurate mass measurements.

\section{ACKNOWLEDGMENT}

The authors are thankful to Wockhardt Research Centre, Aurangabad for providing the gift sample of ARM and SAIFIIT, Mumbai for providing us with the mass spectral studies. The authors also thank JSS College of Pharmacy, Ooty for providing the necessary facilities to carry out the work.

\section{REFERENCES}

[1] WWW.Rx list.com

[2] Tejaswi Jonnalagadda and Shanakumari Katakam, "A simple visible spectrophotometric method for the determination of armodafinil in bulk and pharmaceutical dosage form", Int. J. Pharm Sci Res. vol. 6(6), pp. 2579-2581, June 2015.

[3] P. Vivek Sagar, Nelofer Bagum, and S. Shobha Rani, "Stability indicating RP HPLC method for the estimation armodafinil in tablet dosage form", Int. J. Pharm. Pharma Sci. vol. 6, pp. 604-609, September 2014.

[4] Ramesh Devi, Ramakrishna Singirikonda, and Haiduddin Mohammad, "Development and validation of LC-MS/Ms method for the determination of armodafinil in human plasma", Current Pharm Anal. vol. 8, pp. 295-305, September 2012.

[5] Mamta P. Devadiga, P. Anandan, and Arindam Mukhopadhyay, "Development of a rapid and sensitive method for estimation of armodafinil in human plasma by LC MS/MS”, Int. J. App Bio Pharm Tech. vol. 2, pp. 323-337, MarcPhah 2011.

[6] L. Jennifer Donovan, J.Robert Malcolm, S. John Markowitz, and C. Lindsay Devane, "Chiral analysis of $\mathrm{d}$ - and 1-modafinil in human serum: application of human pharmacokinetic studies", Ther. Drug Monitor. vol. 25, pp. 197-202, April 2003.

[7] Khaldun M. AL Azzam, Bahruddin Saad, Rohana Adnan, and Muhammad Idiris Saleh, "Enantioselective determination of modafinil in pharmaceutical formulations by capillary electrophoresis, and computational calculation of their inclusion complexes", Micro Chim Acta. vol. 166, pp.311-317, September 2009.

[8] R. Nageswara Rao, Dhananjay D. Shinde, and M.V.N. Kumar Talluri, "Development and validation of a reverse phase liquid chromatographic method for separataion and determination of related substancces of modafinil in bulk drugs". Talanta. vol. 73, pp. 407-414, September 2007.

[9] Ramisetti Nageswara rao, Dhananjay D. Shinde, and Murali V.N. Kumar Talluri, "Enantioselective HPLC resolution of synthetic intermediates of armodafinil and related substances”, J. Sep. Sci. vol. 31, pp. 981-989, April 2008.

[10] Wei Wang, Suyun Xiang, Xiaojuan Zhou, Yibing Ji, and Bingren Xiang, "Enantiomeric impurity and determination of the enantiomeric impurity of armodafinil by capillary electrophoresis with sulfobutyl ether $\beta$ cyclodextrin", molecules. vol. 17, pp. 303-314, January 2012.

[11] Mona Darwish, Mary Bond, Edward T. Hellriegel, James M. Youakim, Ronghua Yang, and Philmore Robertson Jr, "Investigation of a possible interaction betwee quetiapine and armodafinil in patients with schizophrenia an open label, multiple dose study", J. Clin Pharmacol. vol. 52, pp. 1399-1409, September 2012.

[12] Deepti Jain and Pawan Basniwal, "Intrinsic stability of armodafinil hydrochloride by forced degradation and impurity profiling", Pharmaceutica Analytica Acta. vol.7, pp. 1-18, February 2016.

[13] ICH, Q1A. Stability Testing of New Drug Substances and Products. International Conference on Harmonization, IFPMA, Geneva, 1993.

[14] ICH, Q2A. Text on validation of analytical procedures, International Conference on Harmonization, October 1994. 


\section{Author Profiles}

Dr. Krishna veni Nagappan is presently working as Professor \& Head in the Department of Pharmaceutical Analysis, JSS College of Pharmacy, ooty, A Constituent College of Jagadguru Shree Shivarathreeshwara University, India. She has published more than 30 papers in national and international peer reviewed journals. Her research area of interest includes impurity profiling of drugs and pharmaceuticals particularly stress degradation studies, characterization of degradation products from pharmaceutials, analytical method development \& validation. She has also presented papers in various national and international conferences.

Ms. Neha Sungroya had completed her Masters Degree in Pharmacy (Pharmaceutical Analysis) from JSS College of Pharmacy, ooty, A Constituent College of Jagadguru Shree Shivarathreeshwara University, India. She is presently persuing her master's degree in pharmacy at Canada.

Ms. Dakshyani D S Devi had completed her Masters Degree in Pharmacy (Pharmaceutical Analysis) from JSS College of Pharmacy, ooty, A Constituent College of Jagadguru Shree Shivarathreeshwara University, India. She is presently associated with Dr. Reddy's Laboratories, Hyderabad as Assistant Manager.

Ms. Sonam Patel is currently persuing her $\mathrm{Ph} \mathrm{D}$ in the Department of Pharmaceutical Analysis, JSS College of Pharmacy, ooty, A Constituent College of Jagadguru Shree Shivarathreeshwara University, India. She is presently working on the project entitled "Isolation, Characterization and Genotoxic Evaluation of the Degradedd Products from Anti Retroviral Agents". She has completed her masters in Pharmaceutical Analysis from NMIM'S University, Mumbai.

Dr. Karthik Yamjala is senior research fellow (ICMR) in Pharmaceutical Analysis at JSS College of Pharmacy, Ooty (JSS University, Mysore), India. He has completed his Master degree in Pharmaceutical Analysis department from the same University in 2013 and PhD in 2017. Dr. Karthik's research mainly focuses on characterization of contaminants in food and pharmaceuticals by various analytical techniques. He published many papers in international journals (Food chemistry, acta chromatographica, scientia pharmaceutica). He is a life member of Indian Pharmaceutical Association.
Dr. Gowramma B is presently working as Assistant Professor in the Department of Pharmaceutical Chemistry, JSS College of Pharmacy, ooty, A Constituent College of Jagadguru Shree Shivarathreeshwara University, India. She has published more than 40 papers in various national and international peer reviewed journals. Her area of research interest includes synthetic chemistry and analytical method development \& validation for chiral compounds.

Dr. Dhanabal S P is presently the Principal, JSS College of Pharmacy, ooty, A Constituent College of Jagadguru Shree Shivarathreeshwara University, India. He is also the Professor in the Department of Phytopharmacy and Phytomedicine. He received many grants from various govermnent agencies viz DST, AICTE etc. His research area of interest includes Herbal Drugs and Formulations. 